\title{
EVALUASI PENATAAN DAN PEMANFAATAN RUANG TERBUKA HIJAU UNTUK INTERAKSI SOSIAL DI RUSUNAWA KOTA CIMAHI
}

\author{
Enrico Nirwan Histanto', Yohanes Karyadi Kusliansjah ${ }^{2}$ \\ Magister Arsitektur, Program Pascasarjana, Universitas Katolik Parahyangan, Bandung \\ Jl. Merdeka, No. 30, Bandung - Indonesia \\ Email: nlr_on3@yahoo.com ${ }^{1}$, karyadi@unpar.ac.id ${ }^{2}$
}

\begin{abstract}
Abstrak
Kota Cimahi pada awalnya merupakan salah satu bagian dari Kabupaten Bandung, dengan pesatnya pertumbuhan akhirnya ditetapkan sebagai kota administratif pada 29 Januari 1976, selanjutnya menjadi kota otonom pada tanggal 21 Juni 2001. Cimahi saat ini menjadi salah satu kawasan pertumbuhan Kota Bandung di bagian Barat. Jumlah penduduknya saat ini adalah 561.386 jiwa, dengan pertumbuhan rata-rata 2,12\% per tahun (sumber: database kependudukan Kota Cimahi tahun 2014).

Ruang Terbuka Hijau (RTH) di beberapa kota di Jawa Barat mengalami penurunan baik dari segi kualitas maupun kuantitas. Hal tersebut berdampak pada penurunan kualitas lingkungan hidup perkotaan dan menimbulkan masalah perkotaan seperti terjadinya bencana banjir, khususnya pada musim penghujan, peningkatan pencemaran udara, dan berkurangnya indeks kebahagiaan kota akibat minimnya ruang terbuka yang tersedia untuk interaksi sosial.

Kesamaan konfigurasi penataan tapak dalam hal ini kesamaan tipologi penyusunan massa bangunan, jumlah penghuni dan sasaran penghuni yaitu masyarakat berpenghasilan rendah (MBR) kedua rusunawa Kota Cimahi, yaitu Cibeureum dan Leuwigajah menarik untuk diteliti manakah yang lebih efektif penataan RTH dan pemanfaatannya serta faktor-faktor penentu apa sajakah yang berperan.

Dalam pengelolaan, pemeliharaan dan pemanfaatan RTH rusunawa memang tanggung jawab utama pengelola rumah susun, dalam hal ini pemerintah Kota Cimahi, namun perlu keterlibatan semua penghuni dalam merawat dan menjaga kebersihannya, khususnya dalam membuang sampah pada tempatnya dan menggunakan sarana yang disediakan dengan bertanggung jawab.
\end{abstract}

Kata kunci: RTH, rusunawa, penataan tapak

\begin{abstract}
Title: Evaluation of Arragement and Use of Green Open Space in Cimai City's Rusunawa

Cimahi City was originally one part of Bandung Regency, with rapid growth finally established as an administrative city on January 29, 1976, then became autonomous city on June 21, 2001. Cimahi currently become one of the growth areas of Bandung in the West. The current population is 561,386, with an average growth of $2.12 \%$ per year (source: population database of Cimahi City 2014).

Green Open Space (RTH) in several cities in West Java has decreased both in terms of quality and quantity. This has the effect of reducing urban environmental quality and causing urban problems such as floods, especially in the rainy season, increasing air pollution, and decreasing urban happiness index due to the lack of open space available for social interaction.

The similarity of the configuration of the arrangement of the site in this case the similarity of the typology of building mass composition, the number of occupants and the target of the residents of low income (MBR) of the two rusunawa Cimahi City, namely Cibeureum and Leuwigajah interesting to
\end{abstract}


examine which is more effective the arrangement of green space and its utilization and the determinants what's playing.

In the management, maintenance and utilization of the flats $R T H$ is the main responsibility of apartment managers, in this case the Cimahi Municipal Government, but the involvement of all residents in maintaining and maintaining cleanliness, especially in disposing of waste in place and use the facilities provided responsibly.

Keywords: RTH, rusunawa, arrangement of site

\section{Pendahuluan}

Kota Cimahi saat ini menjadi salah satu kawasan pertumbuhan Kota Bandung di bagian Barat. Jumlah penduduknya saat ini adalah 561.386 jiwa, dengan pertumbuhan rata-rata $2,12 \%$ per tahun (sumber: database kependudukan Kota Cimahi tahun 2014).

Penataan RTH pada rumah susun sederhana sewa memerlukan konsep dasar yang memenuhi tiga fungsi utama, yaitu: peningkatan kualitas lingkungan hidup, pemenuhan kebutuhan ruang rekreasi ruang luar bagi penghuni rumah susun, termasuk nilai estetika lingkungan dan tersedianya ruang interaksi sosial. Konsep dasar penataan RTH rumah susun sederhana tersebut, didasarkan secara teknis dalam acuan luas minimal, komposisi fasilitas taman/street furniture, dan pemilihan jenis tanaman.

Ruang Terbuka Hijau (RTH) di beberapa kota di Jawa Barat mengalami penurunan baik dari segi kualitas maupun kuantitas. Hal tersebut berdampak pada penurunan kualitas lingkungan hidup perkotaan dan menimbulkan masalah perkotaan seperti terjadinya bencana banjir, khususnya pada musim penghujan, peningkatan pencemaran udara, dan berkurangnya indeks kebahagiaan kota akibat minimnya ruang terbuka yang tersedia untuk interaksi sosial.

Kesamaan konfigurasi penataan tapak dalam hal ini kesamaan tipologi penyusunan massa bangunan, jumlah penghuni dan sasaran penghuni yaitu masyarakat berpenghasilan rendah (MBR) kedua rusunawa Kota Cimahi, yaitu Cibeureum dan Leuwigajah menarik untuk diteliti manakah yang lebih efektif penataan RTH dan pemanfaatannya serta faktor-faktor penentu apa sajakah yang berperan.

Dalam pengelolaan, pemeliharaan dan pemanfaatan RTH rusunawa Cibeureum dan Leuwigajah memang tanggung jawab utama pengelola rumah susun, dalam hal ini pemerintah Kota Cimahi, namun perlu keterlibatan semua penghuni dalam merawat dan menjaga kebersihannya, khususnya dalam membuang sampah pada tempatnya dan menggunakan sarana yang disediakan dengan bertanggung jawab. 


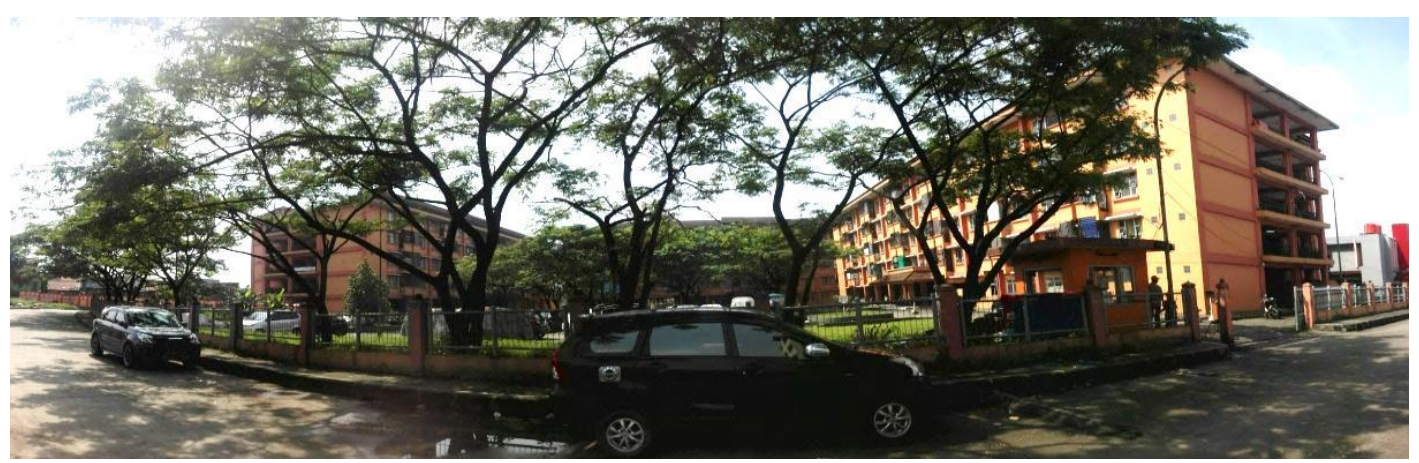

Gambar 1. Rusunawa Cibeureum Cimahi

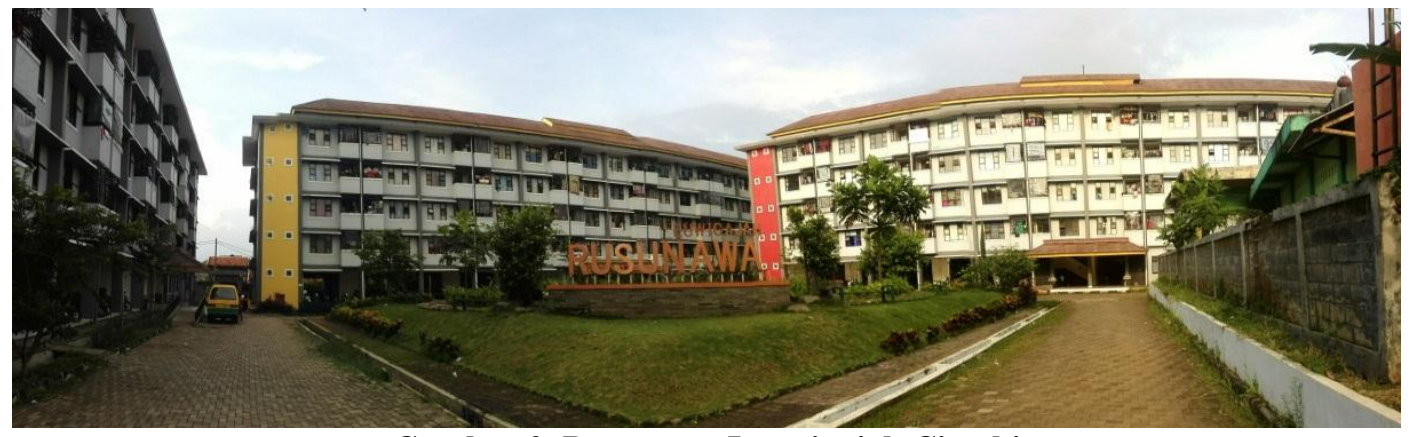

Gambar 2. Rusunawa Leuwigajah Cimahi

\section{Tujuan Penelitian}

1. Mengevaluasi penataan dan pemanfaatan RTH di kedua Rusunawa Cimahi;

2. Menemukan faktor-faktor penentu dalam pemanfaatan RTH di kedua Rusunawa Cimahi.

\section{Manfaat Penelitian}

1. Memberikan masukan kepada Pemerintah Kota Cimahi dalam penyediaan RTH di lingkungan rumah susun sederhana sewa;

2. Memberikan masukan dalam pemeliharaan RTH kepada masyarakat pada umumnya dan masyarakat di Kota Cimahi pada khususnya.

\section{Metode Penelitian}

Metode dalam penelitian ini bersifat POE/Post Ocupancy Evaluation dengan pendekatan analisis deskriptif melalui analisis kualitatif dan kuantitatif. Analisis deskriptif berguna untuk mengevaluasi kondisi dan tingkat pemanfaatan RTH, sedangkan analisis kualitatif dan kuantitatif berguna untuk mengetahui kualitas penataan dan kecukupan RTH di area kedua rumah susun sederhana sewa (rusunawa) tersebut. Dalam proses penelitian ini terdapat dua jenis pengumpulan data, data primer dan sekunder. Data primer didasarkan pada pengamatan langsung di lapangan, wawancara dengan kepala pengelola rusunawa dan penyebaran kuesioner kepada penghuni atau pengguna RTH. Sedangkan data sekunder diperoleh dari berbagai sumber 
lainnya seperti studi literatur, data statistik, dan berbagai sumber di internet.

\section{Landasan Teori}

\section{Dasar Perencanaan Rumah Susun}

Pembangunan rumah susun merupakan salah satu solusi pemenuhan kebutuhan perumahan yang layak bagi masyarakat berpenghasilan rendah (MBR). Oleh karena itu, memerlukan suatu standar perencanaan dalam pembangunannya.

Standar perencanaan rumah susun di kawasan perkotaan didasarkan pada Kebijakan dan Rencana Strategis Pembangunan Rumah Susun di Perkotaan Tahun 2007, yaitu:

1. Kepadatan Bangunan

Pengaturan intensitas/kepadatan bangunan merupakan komposisi dari perbandingan data-data luas lahan peruntukan, kepadatan bangunan, Koefisien Dasar Bangunan (KDB) dan Koefisien Lantai Bangunan (KLB).

- Koefisien Dasar Bangunan (KDB) adalah perbandingan antara luas dasar bangunan dengan luas lahan/persil, dimana nilainya tidak melebihi dari angka 0,4;

- Koefisien Lantai Bangunan (KLB) adalah perbandingan antara luas lantai bangunan dengan luas tanah, dimana nilainya tidak kurang dari angka 1,5 ;

- Koefisien Bagian Bersama (KB) adalah perbandingan Bagian Bersama dengan luas bangunan, dimana nilainya tidak kurang dari angka 0,2 .

2. Lokasi
Kebijakan pembangunan rumah susun harus berada di lokasi yang sesuai dengan tata ruang kota, rencana tata bangunan dan lingkungan, terjangkau dengan layanan transportasi umum, termasuk memperhatikan keserasian dengan lingkungan sekitar.

3. Tata Letak

Rumah susun harus memperhatikan keterpaduan bangunan, lingkungan, kawasan dan ruang, faktor-faktor kemanfaatan, keselamatan, keserasian dan keseimbangan.

4. Jarak Antar Bangunan dan Ketinggian

Sesuai dengan persyaratan terhadap bahaya kebakaran, pencahayaan, sirkulasi udara alami, kenyamanan, dan kepadatan bangunan berdasarkan tata ruang kota.

5. Jenis Fungsi Rumah Susun

Rumah susun berfungsi sebagai hunian dan dimungkinkan dalam satu rumah susun/kawasan rumah susun memiliki jenis kombinasi fungsi hunian dan usaha.

6. Luasan Satuan Rumah Susun

Dimensi luas satuan rumah susun (Sarusun) adalah minimum $21 \mathrm{~m}^{2}$, dimana fungsi utama sebagai ruang tidur atau ruang serba guna yang dilengkapi kamar mandi dan dapur.

7. Kelengkapan Rumah Susun

Fasilitas berupa prasarana, sarana, dan utilitas yang menunjang kesejahteraan, kelancaran, dan kemudahan penghuni dalam menunjang kegiatan harian.

8. Transportasi Vertikal

- Rumah susun bertingkat rendah dengan kriteria jumlah lantai maksimum 6 lantai, menggunakan tangga sebagai transportasi vertikal; 
- Rumah susun bertingkat tinggi dengan kriteria jumlah lebih dari 6 lantai, menggunakan lift sebagai transportasi vertikal.

\section{Ruang Terbuka Hijau}

Ruang Terbuka Hijau atau disingkat RTH adalah bagian dari ruang terbuka yang pemanfaatanya sebagai tempat tumbuh tanaman, baik secara alami maupun yang sengaja ditanam, sebagai lahan pertanian, pertamanan, perkebunan dan sebagainya (UU RI No. 26 Tahun 2007). Berdasarkan Pemendagri No. 1 Tahun 2007, ruang terbuka mempunyai pengertian sebagai ruang-ruang dalam kota atau wilayah yang lebih luas, baik dalam bentuk area atau kawasan maupun dalam bentuk area memanjang, dimana dalam pemanfaatannya lebih bersifat terbuka tanpa elemen penutup bangunan. Sesuai Perda No. 6 Tahun 1999, RTH merupakan lahan atau areal permukaan tanah yang didominasi oleh tumbuhan yang dibina untuk fungsi perlindungan habitat tertentu, daratan kota/lingkungan, pengaman jaringan prasarana, dan budidaya pertanian.

Standar luas ruang terbuka untuk umum menurut Simonds (2003) yaitu:

Tabel 1. Standar luas minimum ruang terbuka, Simonds (2003)

\begin{tabular}{|c|l|}
\hline Unit Sosial & \multicolumn{1}{c|}{ Luas Minimum Ruang Terbuka } \\
\hline $\begin{array}{c}\text { Keluarga } \\
\text { (rata-rata 3-6 jiwa) }\end{array}$ & $\begin{array}{l}\text { - Untuk setiap keluarga, duplex atau row house minimum } 27 \mathrm{~m}^{2} \text { ruang } \\
\text { bebas, tertutup, tidak termasuk tempat parkir. } \\
\text { - Untuk bangunan bertingkat, minimum } 9 \mathrm{~m}^{2}\end{array}$ \\
\hline $\begin{array}{c}\text { Cluster } \\
(3-10 \text { keluarga, } \\
11-43 \text { jiwa) }\end{array}$ & $\begin{array}{l}-18 \mathrm{~m}^{2} \text { per unit rumah tinggal yang dapat diperluas, dilengkapi tempat } \\
\text { duduk, pohon, patung, air mancur, semak-semak, bunga, rumput } \\
\text { ataupun perlengkapan bermain. }\end{array}$ \\
\hline $\begin{array}{c}\text { Ketetanggaan } \\
(1.200 \text { keluarga, } \\
4.320 \text { jiwa) }\end{array}$ & $\begin{array}{l}\text { - Minimum 12.000 m per } 1000 \text { penduduk disediakan untuk lapangan } \\
\text { bermain sekolah, rekreasi atau taman. Daerah ini tidak termasuk } \\
\text { daerah untuk parkir kendaraan. }\end{array}$ \\
\hline
\end{tabular}

\section{Ruang Terbuka Hijau Permukiman}

Dalam upaya peningkatan kualitas lingkungan permukiman, salah satunya adalah penyediaan RTH bagi masyarakat, yang dapat juga berfungsi sebagai tempat interaksi sosial warga, sarana dan prasarana bermain bagi anakanak serta menampung berbagai aktivitas sosial kemasyarakatan lainnya. Manfaat lain dari RTH antara lain sebagai daerah resapan air yang dapat mengurangi bahaya banjir, khususnya pada musim penghujan, menjadikan udara sekitar sehat dan bersih. Tanaman sangat berfungsi dalam menentukan kualitas ruang terbuka yang bervegetasi, karena mampu meredam kebisingan yang ditimbulkan kendaraan bermotor dan sebagai pereduksi suhu melalui peningkatan kelembaban udara (Captenter et.al. 1975). Sesuai Dirjen Penataan Ruang Departemen PU, 2006 
tentang jenis tanaman di RTH, antara lain: tahan terhadap hama dan penyakit, cepat tumbuh, berumur relatif panjang, mempunyai bentuk yang indah, serbuk sarinya tidak mengakibatkan alergi, serta daun dan akarnya tidak mempunyai sifat mematikan tanaman lain disekitarnya.

Peran utama pengelola rusunawa dalam pemeliharaan RTH, antara lain: kegiatan penyiraman, pembersihan, pemangkasan, maupun penggantian tanaman yang sakit atau mati, dan penanaman kembali. Penempatan pot tanaman dan ukurannya perlu disesuaikan dengan ketersediaan ruang, sehingga tetap proporsional antara tanaman pelindung, tanaman perdu, semak-semak dan sekitarnya.

Tabel 2. Standar kebutuhan ruang terbuka hijau-Dirjen Penataan Ruang Departemen PU, 2006

\begin{tabular}{|c|c|c|c|c|c|}
\hline Unit Lingkungan & $\begin{array}{l}\text { Jenis Ruang } \\
\text { Terbuka yang } \\
\text { Dibutuhkan }\end{array}$ & $\begin{array}{l}\text { Jumlah Penduduk } \\
\text { yang Mendukung } \\
\text { (jiwa) }\end{array}$ & $\begin{array}{c}\text { Jumlah } \\
\text { Luas/Unit } \\
\left(\mathrm{m}^{2}\right)\end{array}$ & $\begin{array}{c}\text { Standar/ } \\
\text { Kapita } \\
\text { (m²/jiwa) }\end{array}$ & Lokasi \\
\hline L-I & $\begin{array}{l}\text { Tempat bermain } \\
\text { Anak-anak }\end{array}$ & 250 & 260 & 1.0 & Di tengah kelompok pemukiman (RT) \\
\hline$L-\|$ & $\begin{array}{c}\text { Taman + } \\
\text { Lapangan Olahraga }\end{array}$ & 3.000 & 1.500 & 0.5 & Di pusat kegiatan RW (RW) \\
\hline$L-|| \mid$ & $\begin{array}{c}\text { Taman + } \\
\text { Lapangan Olahraga }\end{array}$ & 30.000 & 10.000 & 0.33 & Dikelompokkan dengan sekolah (Kelurahan) \\
\hline L-IV & $\begin{array}{c}\text { Taman + } \\
\text { Stadion Kecil }\end{array}$ & 200.000 & 40.000 & 0.2 & Dikelompokkan dengan sekolah (Kecamatan) \\
\hline L-V & $\begin{array}{c}\text { Taman Kota + } \\
\text { Kompleks Stadion }\end{array}$ & 1.000 .000 & 150.000 & 1.5 & Di pusat wilayah/tersendiri (Wilayah Kota) \\
\hline \multirow[t]{3}{*}{ Penyempurnaan } & Pemakaman & & & 0.58 & Di luar pusat wilayah (pinggir kota) \\
\hline & Hutan Kota & & & 6.0 & Digabung dalam kesatuan yang kompak \\
\hline & Jalur Hiljau & & & 15.0 & Tersebar \\
\hline
\end{tabular}

\section{Psikologi Perkembangan}

Merupakan cabang dari ilmu psikologi yang mempelajari perkembangan dan perubahan aspek kejiwaan manusia sejak dilahirkan sampai dengan meninggal. Terapan dari ilmu psikologi perkembangan digunakan di berbagai bidang seperti pendidikan dan pengasuhan, organisasi-industri, pengoptimalan kualitas hidup dewasa tua, dan penanganan remaja.

Pembagian usia terhadap kesadaran dan pola sosial menurut Elizabeth B. Hurlock (Hurlock, 2005) adalah sebagai berikut: 
Tabel 3. Rangkuman pembagian usia, Elizabeth B. Hurlock (Hurlock, 2005)

\begin{tabular}{|c|c|}
\hline Perkembangan & Perilaku Sosial \\
\hline $\begin{array}{c}\text { Masa Kanak-kanak } \\
(1-6 \text { tahun) }\end{array}$ & $\begin{array}{l}\text { - Tahap meniru, agar sama dalam kelompok, anak meniru sikap dan perilaku orang } \\
\text { yang sangat ia kagumi. } \\
\text { - Kerja sama, pada usia } 3 \text { tahun bermain kooperatif dan kegiatan kelompok mulai } \\
\text { berkembang. } \\
\text { - Tahap persaingan, keinginan untuk tidak mau kalah dari teman-temannya muncul } \\
\text { mulai usia } 4 \text { tahun. }\end{array}$ \\
\hline $\begin{array}{c}\text { Masa Akhir Anak-anak } \\
\text { (7-8 tahun) }\end{array}$ & $\begin{array}{l}\text { - Usia berkelompok, dimana minat terhadap aktivitas fisik bersama teman sebaya } \\
\text { dan keinginan kuat untuk diterima sebagai anggota suatu kelompok. } \\
\text { - Anak tidak lagi puas bermain sendiri di rumah atau dengan anggota keluarganya. }\end{array}$ \\
\hline $\begin{array}{l}\text { Masa Puber } \\
(9-17 \text { tahun) }\end{array}$ & $\begin{array}{l}\text { - Kecenderungan untuk menyendiri atau menarik diri dari teman-teman, sering } \\
\text { bertengkar dengan teman sebaya dan dengan anggota keluarga. } \\
\text { - Hilangnya rasa percaya diri dan takut akan kegagalan dalam proses penemuan } \\
\text { jati diri mereka. }\end{array}$ \\
\hline $\begin{array}{l}\text { Masa Remaja } \\
\text { (18-29 tahun) }\end{array}$ & $\begin{array}{l}\text { - Termasuk dalam masa perkembangan tersulit dalam kehidupan, karena harus } \\
\text { menyesuaikan diri dengan lawan jenis dan harus menyesuaikan dengan orang } \\
\text { dewasa di luar lingkungan keluarga dan sekolah. } \\
\text { - Tahap penyesuaian diri antara nilai-nilai di keluarga dan di masyarakat. }\end{array}$ \\
\hline $\begin{array}{c}\text { Masa Dewasa Dini } \\
\text { (30 tahun) }\end{array}$ & $\begin{array}{l}\text { - Kehidupan sosial pada tahap awal, tahap pembinaan keluarga muda, berpusat di } \\
\text { rumah dan anggota-anggota keluarga menggantikan peran teman. } \\
\text { - Pada tahap selanjutnya, peran serta dalam kegiatan sosial di luar rumah } \\
\text { meningkat menjelang usia setengah baya yaitu sampai usia } 30 \text { tahun }\end{array}$ \\
\hline $\begin{array}{l}\text { Usia Madya } \\
\text { (40-50 tahun) }\end{array}$ & $\begin{array}{l}\text { - terjadi peningkatan dalam kehidupan sosial, karena tanggung jawab keluarganya } \\
\text { berkurang karena usia anak sudah dewasa dan status ekonomi yang meningkat. } \\
\text { - pria pada umumnya mempunyai lebih banyak teman dan kerabat daripada wanita, } \\
\text { namun wanita mempunyai hubungan yang lebih dekat dengan anggota kerabat } \\
\text { keluarga. } \\
\text { - pria dan wanita yang berusia sekitar } 50 \text { tahun cenderung menghabiskan } \\
\text { waktunya dengan anggota kerabat dekat. }\end{array}$ \\
\hline $\begin{array}{l}\text { Usia Lanjut } \\
\text { (>50 tahun) }\end{array}$ & $\begin{array}{l}\text { - kelompok dari status sosial yang tinggi cenderung terus melakukan banyak } \\
\text { keinginan yang telah dikembangkan pada masa awal kehidupannya } \\
\text { - tingkat kesehatan yang cenderung menurun, berdampak pada menurunnya } \\
\text { kegiatan sosial di luar rumah }\end{array}$ \\
\hline
\end{tabular}

Tabel 4. Pembagian usia, Wikipedia Indonesia

\begin{tabular}{|l|l|l|}
\hline \multicolumn{1}{|c|}{ Masa } & \multicolumn{1}{c|}{ Usia } & Status pekerjaan \\
\cline { 1 - 2 } Bayi & $0-3$ tahun & \multirow{2}{*}{ Non produktif } \\
\cline { 1 - 2 } Balita & $4-6$ tahun & \\
\cline { 1 - 2 } Anak & $7-12$ tahun & \\
\cline { 1 - 2 } Remaja & $13-18$ tahun & \multirow{2}{*}{ Produktif } \\
\cline { 1 - 2 } Dewasa awal & $19-39$ tahun & \\
\cline { 1 - 2 } Dewasa tengah & $40-60$ tahun & \\
\hline Dewasa akhir (lansia) & $\geq 61$ tahun & Non produktif \\
\hline
\end{tabular}

\section{Hasil dan Pembahasan}

Penelitian ini dilakukan dari tanggal 2329 Juli 2017, selama 1 minggu dimulai dari hari Minggu dan berakhir pada hari Sabtu. Setiap harinya dimulai dari pk.06.00-10.00 (pagi), pk.10.00-14.00 (siang), pk.14.00-18.00 (sore) dan pk.18.00-22.00 (malam). Alat-alat yang digunakan selama penelitian adalah kamera, perekam video, tripot, dan kuesioner.

\section{Analisis Kepadatan Bangunan}

Analisis dilakukan dengan membandingkan perhitungan $\mathrm{KDB}$, KLB, dan Bagian Bersama di kedua rusunawa dengan standar yang berlaku.

Tapak kedua rusunawa terdiri dari 3 massa bangunan utama (Gedung A,B, dan C) yang berfungsi sebagai hunian (5 lantai, 96 unit hunian), dengan tipe hunian $24 \mathrm{~m}^{2}\left(6 \times 4 \mathrm{~m}^{2}\right)$ dengan fasilitas di lantai 1, yaitu: parkir motor, lobby utama, unit hunian bagi penyandang 
disabilitas, meter listrik, mushola, ruang serba guna dan WC umum.

Hal ini dimungkinkan karena keduanya dibangun dan dikelola oleh Pemerintah Kota Cimahi. Dimana Rusunawa Cibeureum dibangun pada tahun 2007-

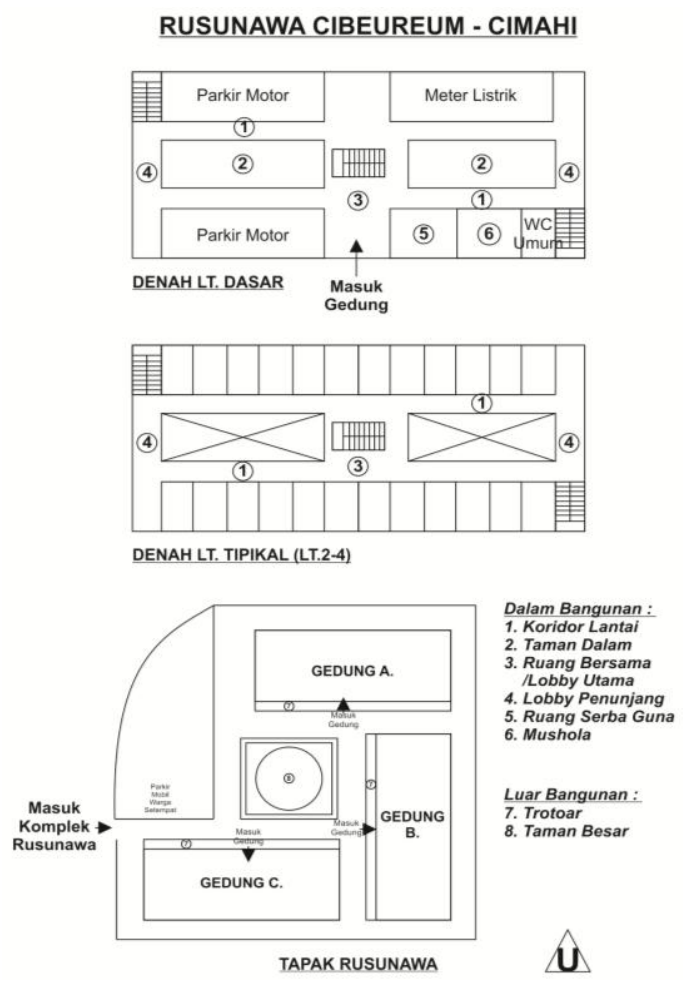

2009 (tahun pengoperasian 2010) sedangkan Rusunawa Leuwigajah dibangun pada tahun 2010-2013 (tahun pengoperasian 2014).
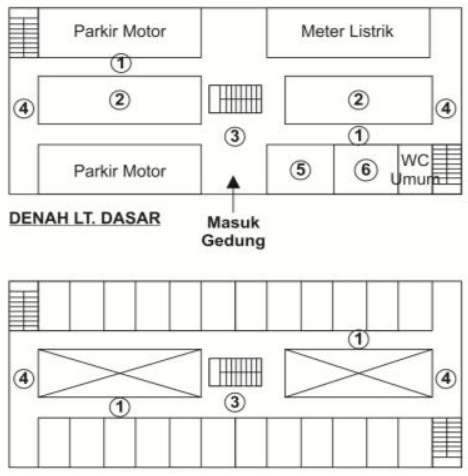

DENAH LT. TIPIKAL (LT.2-4)

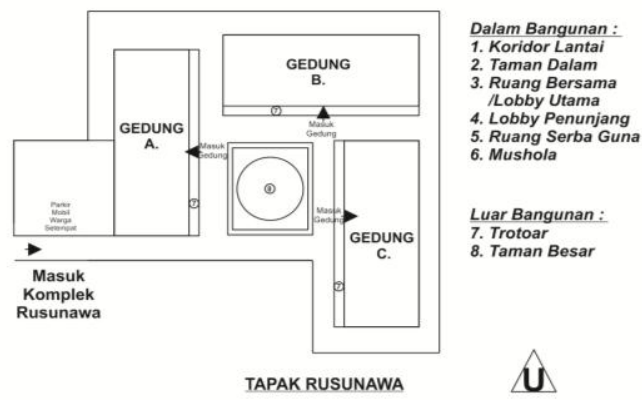

Gambar 3. Hasil pengamatan di lokasi

Rusunawa Cibeureum :

Luas Lahan : $6000 \mathrm{~m}^{2}$; Luas Dasar Seluruh Bangunan : $1.800 \mathrm{~m}^{2}$; Luas Seluruh Lantai Bangunan : $9000 \mathrm{~m}^{2}$; $\mathrm{RTH}$ : $2000 \mathrm{~m}^{2}$; Bagian Bersama : $2500 \mathrm{~m}^{2}$ (Taman + Area Bersama) $\mathrm{KDB}=1800 / 6000=0.3($ Standar $<=$ $0,4)$

$\mathrm{KLB}=9000 / 6000=1.5($ Standar $>1,5)$

Bagian bersama $=2500 / 9000=0.28$ (Standar $>=0,2)$

Rusunawa Leuwigajah :

Luas Lahan : $4000 \mathrm{~m}^{2}$; Luas Dasar Seluruh Bangunan : $1.600 \mathrm{~m}^{2}$; Luas
Seluruh Lantai Bangunan : $6400 \mathrm{~m}^{2}$; RTH : $1000 \mathrm{~m}^{2}$; Bagian Bersama : 1500 $\mathrm{m}^{2}$ (Taman + Area Bersama)

$\mathrm{KDB}=1600 / 4000=0.4($ Standar $<=$ $0,4)$

$\mathrm{KLB}=6400 / 4000=1.6($ Standar $>1,5)$

Bagian bersama $=1500 / 6400=0.12$ (Standar $>=0,2$ )

Berdasarkan perhitungan mengenai kepadatan bangunan Rusunawa Cibeureum yang paling memenuhi standar karena terpenuhinya ketiga standar untuk KDB, KLB dan Bagian Bersama dibandingkan dengan Rusunawa Leuwigajah pada area Bagian 
Bersama memiliki angka 0.12 dibawah angka standar 0,2, yang berarti masih perlu ditambah.
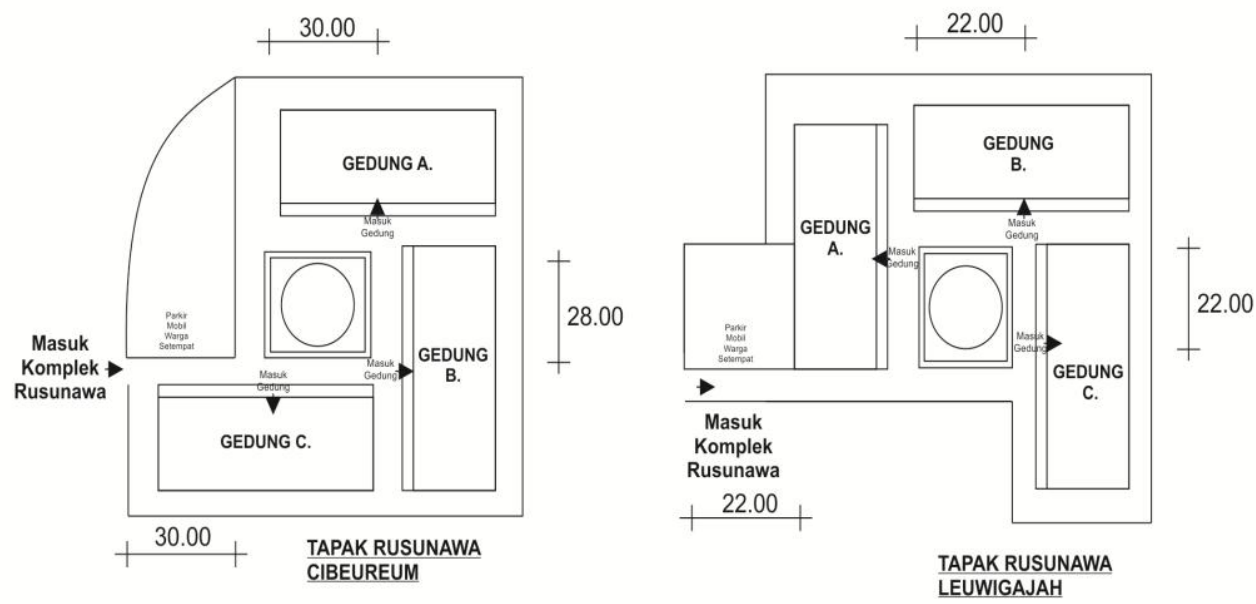

Gambar 4. Hasil pengamatan di lokasi

Analisis Ruang Terbuka Hijau

A. Perbandingan RTH dengan Jumlah Penghuni

Berdasarkan Dirjen Panataan Ruang

Departemen PU, 2006 tentang standar kecukupan RTH di permukiman berdasarkan luas RTH/jiwa yaitu minimal $1 \mathrm{~m}^{2} /$ jiwa.

Tabel 5. Perbandingan RTH dengan jumlah penghuni

\begin{tabular}{|c|l|c|c|c|c|}
\hline No. & Rusunawa & $\begin{array}{c}\text { Jumlah } \\
\text { Penghuni } \\
\text { (jiwa) }\end{array}$ & $\begin{array}{c}\text { Luas } \\
\mathbf{R T H} \\
\mathbf{( m}^{\mathbf{2}} \mathbf{)}\end{array}$ & $\begin{array}{c}\text { Luas } \\
\text { RTH/jiwa }\end{array}$ & Kecukupan \\
\hline 1. & Cibeureum & 888 & 2000 & 2.25 & Cukup \\
\hline 2. & Leuwigajah & 885 & 1000 & 1.13 & Cukup \\
\hline
\end{tabular}

Berdasarkan Tabel 5. didapatkan hasil kedua rusunawa tersebut mencukupi standar, Rusunawa Cibeureum (2.25) sedangkan Rusunawa Leuwigajah (1.13) dari angka yang yang telah ditetapkan $\left(1 \mathrm{~m}^{2} /\right.$ jiwa $)$.
B. Perbandingan Lahan terhadap RTH pada Rusunawa

Berdasarkan Undang-undang RI No. 26 Tahun 2007 tentang Penataan Ruang, bahwa luas RTH 30\% dari luas lahan yang ada. 
Tabel 6. Perbandingan RTH dengan jumlah penghuni

\begin{tabular}{|c|c|c|c|c|c|}
\hline No. & Rusunawa & $\begin{array}{c}\text { Luas } \\
\text { Lahan } \\
\left(\mathrm{m}^{2}\right)\end{array}$ & $\begin{array}{l}\text { Luas } \\
\text { RTH } \\
\left(\mathrm{m}^{2}\right)\end{array}$ & $\begin{array}{c}\text { Persentase } \\
\text { Kecukupan } \\
(\%)\end{array}$ & Kecukupan \\
\hline 1. & Cibeureum & 6000 & 2000 & 33.33 & Mencukupi \\
\hline 2. & Leuwigajah & 4000 & 1000 & 25 & Tidak \\
\hline
\end{tabular}

Berdasarkan Tabel 6. terlihat bahwa kompoisisi RTH Rusunawa Cibeureum (33.33\%) telah mencukupi standar dibandingakan dengan Rusunawa Leuwigajah (25\%), dibandingkan dengan angka standar $30 \%$.

\section{Perbandingan Kondisi RTH pada Rusunawa}

Gambaran fasilitas/perabot yang ada di RTH kedua rusunawa terdiri dari bangku taman, tempat sampah, pepohonan tinggi dan rendah serta rumput.
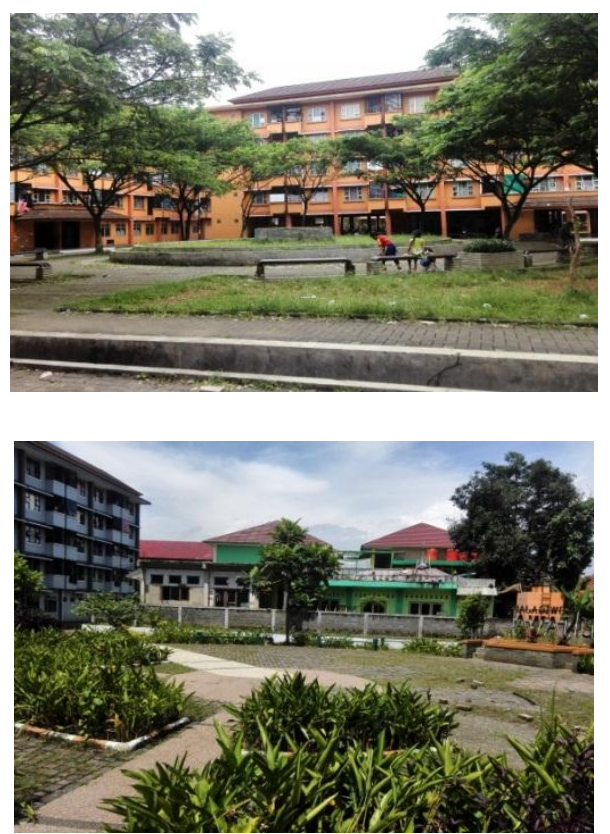

Gambar 5. Taman besar tengah rusunawa Cibeureum (atas) dan Leuwigajah (bawah)

Tabel 7. Ruang terbuka hijau rusunawa Cibeureum dan Leuwigajah

\begin{tabular}{|c|l|l|c|c|c|c|c|}
\hline No. & Rusunawa & Pengelola & $\begin{array}{c}\text { Kondisi } \\
\text { RTH }\end{array}$ & $\begin{array}{c}\text { Kondisi } \\
\text { Fasilitas }\end{array}$ & Kebersihan & $\begin{array}{c}\text { Suasana } \\
\text { RTH }\end{array}$ & Kenyamanan \\
\hline 1. & Cibeureum & $\begin{array}{l}\text { Pemerintah } \\
\text { Kota Cimahi }\end{array}$ & $\begin{array}{c}\text { Kurang } \\
\text { Terawat }\end{array}$ & Kurang & Bersih & $\begin{array}{c}\text { Teduh, } \\
\text { nyaman }\end{array}$ & $\begin{array}{c}\text { Nyaman } \\
(60 \%)\end{array}$ \\
\hline 2. & Leuwigajah & $\begin{array}{l}\text { Pemerintah } \\
\text { Kota Cimahi }\end{array}$ & $\begin{array}{c}\text { Kurang } \\
\text { Terawat }\end{array}$ & Sedang & Bersih & $\begin{array}{c}\text { Panas } \\
\text { (siang hari) }\end{array}$ & $\begin{array}{c}\text { Tidak } \\
\text { Nyaman (40\%) }\end{array}$ \\
\hline
\end{tabular}




\section{Analisis Pemanfaatan Ruang Terbuka \\ Hijau}

Tabel 8. Jumlah pengguna fasilitas bersama berdasarkan pengamatan (kolom abu-abu: rusunawa Cibeureum; kolom putih: rusunawa Leuwigajah)

Pengguna Fasilitas Bersama

\begin{tabular}{|c|c|c|c|c|c|c|c|c|c|c|}
\hline Hari & Tanggal & $\mathrm{Pa}$ & & Siar & & So & & Mal & lam & Total \\
\hline Minggu & $23 / 6$ & 30 & 21 & 23 & 16 & 28 & 20 & 15 & 11 & 164 \\
\hline Seni & $24 / 6$ & 18 & 15 & 20 & 15 & 25 & 18 & 12 & 0 & \\
\hline & & 17 & 16 & 21 & 15 & 24 & 18 & 14 & 11 & \\
\hline & & 17 & 15 & 22 & 16 & 26 & 25 & 16 & 14 & \\
\hline & & 20 & 15 & 21 & 17 & 24 & 19 & 15 & 12 & \\
\hline & & 17 & 15 & 23 & 17 & 25 & 21 & 15 & 15 & 148 \\
\hline Sabtu & $29 / 6$ & 22 & 20 & 24 & 18 & 26 & 25 & 16 & 18 & 169 \\
\hline & & & & & & & & & 91 & \\
\hline
\end{tabular}

Berdasarkan tabel 8. data pengguna yang digunakan untuk analisa adalah hari Sabtu, 29 Juli 2017 dengan pertimbangan adalah pengguna fasilitas bersama terbanyak di kedua rusunawa, dengan total pengguna di Rusunawa Cibeureum 88 orang dan Leuwigajah 81 orang.

Tabel 9. Profil pengguna RTH (kolom abu-abu: rusunawa Cibeureum; kolom putih: rusunawa Leuwigajah)

Profil Pengguna

\begin{tabular}{|c|c|c|c|c|c|c|c|c|c|c|c|c|c|}
\hline \multirow{3}{*}{$\begin{array}{c}\text { No. } \\
1 .\end{array}$} & \multirow{3}{*}{$\begin{array}{l}\text { Responden } \\
\text { Pria }\end{array}$} & \multicolumn{12}{|c|}{ Kelompok Usia } \\
\hline & & \multirow{2}{*}{\begin{tabular}{|c|}
$\begin{array}{c}\text { Bayi } \\
\text { 0-3th }\end{array}$ \\
21
\end{tabular}} & \multicolumn{2}{|c|}{$\begin{array}{l}\text { Balita } \\
\text { 4-6th }\end{array}$} & \multirow{2}{*}{\begin{tabular}{|c|}
$\begin{array}{c}\text { Anak } \\
7-12 \text { th }\end{array}$ \\
1011
\end{tabular}} & \multicolumn{2}{|c|}{$\begin{array}{l}\text { Remaja } \\
13-18 \text { th }\end{array}$} & \multicolumn{2}{|c|}{$\begin{array}{c}\text { Dewasa } \\
\text { Awal } \\
\text { 19-39th }\end{array}$} & \multicolumn{2}{|c|}{$\begin{array}{l}\text { Dewasa } \\
\text { Tengah } \\
\text { 40-60th }\end{array}$} & \multicolumn{2}{|c|}{$\begin{array}{c}\text { Dewasa } \\
\text { Akhir } \\
>=61 \text { th }\end{array}$} \\
\hline & & & 4 & 3 & & 10 & 10 & 7 & 7 & 6 & 4 & 4 & 5 \\
\hline 2. & Wanita & 21 & 2 & 3 & 1112 & 10 & 9 & 7 & 6 & 10 & 3 & 3 & 6 \\
\hline
\end{tabular}

target utamanya adalah dari golongan MBR dengan usia pernikahan muda (berdasarkan teori Psikologi Perkembangan rata-rata usia 20-35 tahun yang termasuk usia produktif).
Dilakukan pengamatan terhadap jenis fasilitas bersama baik di dalam maupun di luar ruangan dibandingkan dengan kelompok usia pengguna sesuai dengan teori psikologi perkembangan. 
Tabel 10. Jenis kegiatan di RTH dibandingkan dengan usia berdasarkan pengamatan, (kolom abu-abu: rusunawa Cibeureum; kolom putih: rusunawa Leuwigajah)

\begin{tabular}{|c|c|c|c|c|c|c|c|c|c|c|c|c|c|c|c|}
\hline \multirow{3}{*}{$\begin{array}{r}\text { No. } \\
1 .\end{array}$} & \multirow{3}{*}{$\begin{array}{l}\text { Jenis Kegiatan } \\
\text { raga / Bermain }\end{array}$} & \multicolumn{14}{|c|}{ Kelompok Usia } \\
\hline & & \multicolumn{2}{|c|}{ Bayi } & \multicolumn{2}{|c|}{ Balita } & \multicolumn{2}{|c|}{ Anak } & \multicolumn{2}{|c|}{ Remaja } & \multicolumn{2}{|c|}{$\begin{array}{c}\text { Dewasa } \\
\text { Awal }\end{array}$} & \multicolumn{2}{|c|}{$\begin{array}{l}\text { Dewasa } \\
\text { Tengah }\end{array}$} & \multicolumn{2}{|c|}{$\begin{array}{c}\text { Dewasa } \\
\text { Akhir }\end{array}$} \\
\hline & & 0 & 0 & 4 & 4 & 6 & 5 & 8 & 4 & 0 & 0 & 0 & 0 & 0 & 0 \\
\hline 2. & Menggunakan media sosial & 0 & 0 & 0 & 0 & 4 & 0 & 6 & 4 & 2 & 4 & 2 & 0 & 0 & 2 \\
\hline 3. & Melakukan hobi & 0 & 0 & 0 & 0 & 0 & 0 & 0 & 0 & 0 & 0 & 0 & 0 & 0 & 0 \\
\hline 4. & Berte & 0 & 0 & 0 & 0 & 0 & 0 & 0 & 0 & 0 & C & 0 & 0 & 0 & 0 \\
\hline 5. & Bertemu tam & 0 & 0 & 0 & 0 & 0 & 0 & 0 & 0 & 2 & & 3 & 0 & 0 & 0 \\
\hline 6. & Berjalan-jalan di area komplek & 0 & 0 & 0 & 2 & 7 & 9 & 0 & 4 & 4 & 2 & 4 & 3 & 3 & 6 \\
\hline 7. & Duduk di taman & 4 & 2 & 2 & 0 & 4 & 9 & 6 & 8 & 6 & 7 & 2 & 4 & 4 & 3 \\
\hline
\end{tabular}

Berdasarkan tabel 10. didapatkan tempat berkumpul penghuni untuk karakteristik pengguna RTH di bersosialisasi dan berekreasi, juga Rusunawa Cibeureum didominasi usia memberikan kontribusi positif terhadap anak, remaja, dewasa awal dan tengah sedangkan Leuwigajah didominiasi usia anak, remaja dan dewasa awal saja. Pemanfaaan di Rusunawa Cibeureum lebih banyak usia karena, pertama, secara kualitas suasana dan kenyamanan lebih nyaman dan teduh, kedua, dimungkinkan penggunaannya secara bebas bagi warga sekitar sedangkan di Rusunawa Leuwigajah terbatas hanya bagi penghuni dan tamu berizin saja, lebih karena alasan keamanan.

\section{Kesimpulan}

Keterbatasan lahan di kota, tidak boleh dijadikan alasan untuk mengintervensi RTH dalam skala kawasan, kota maupun rusun. Kehadiran RTH di area rusunawa berdampak kepada lingkungan perumahan sekitarnya, selain sebagai peningkatan kualitas lingkungan dan nilai estetika atau keindahan.

Penghuni kedua rusunawa tersebut secara umum sudah merasa puas dengan kehadiran RTH yang ada. Mengingat dengan besarnya uang sewa perbulannya yang relatif terjangkau (Rp.300.000/bulan). Harapan penghuni yaitu RTH semakin dilengkapi dengan berbagai variasi fasilitas rekreasi terutama sarana bermain anak (Rusunawa Cibeureum belum tersedia) dan untuk orang dewasa menginginkan adanya tempat mengisi daya untuk telepon genggam, lapangan olahraga (futsal), dan ditanami pohon peneduh yang lebih banyak (khususnya di Rusunawa Leuwigajah).

Pola pemanfaatan RTH di kedua rusunawa terangkum pada tabel di bawah ini, yaitu:

Tabel 11. Kesimpulan pemanfaatan RTH

\begin{tabular}{|c|l|l|c|l|}
\hline No. & \multicolumn{2}{|c|}{ Waktu Kegiatan } & $\begin{array}{c}\text { Jenis } \\
\text { Kegiatan }\end{array}$ & \multicolumn{1}{c|}{ Pengguna } \\
\hline 1. & Pagi & pk.06.00-10.00 & Olah Raga / Bermain & Bayi, Anak, Remaja \\
\hline 2. & Siang & pk.10.00-15.00 & Mengobrol & Remaja, Dewasa Awal, Dewasa Tengah \\
\hline 3. & Sore & pk.15.00-18.00 & Berialan di komplek & Remaja, Dewasa Awal, Dewasa Tengah \\
\hline 4. & Malam & pk.18.00-22.00 & Duduk di taman & Anak, Remaja, Dewasa Awal \\
\hline
\end{tabular}


Berdasarkan tabel 11. usia remaja terlihat mendominasi penggunaan dari jenis kegiatan olah raga, mengobrol, berjalan di komplek dan duduk di taman. Hal ini dapat dipahami karena usia remaja merupakan usia dimulai pencarian jati diri melalui keterlibatan dalam masyarakat dan inginnya menerima pengakuan dari teman-teman sebayanya.

\section{Daftar Pustaka}

Carpenter, P.L.T.D. Walker dan F.O. Lanphear. 1975. Plants in The Landscape. W.H. Freemen and Company. San Fransisco.

Hurlock, Elizabeth B. 2005. Psikologi Perkembangan.

Simonds, J.O. 2003. Landscape Architecture. McGraw-Hill Book Co.New York.

UU Republik Indonesia Nomor 16 Tahun 1985 Tentang Rumah Susun

PP Republik Indonesia Nomor 4 Tahun 1988 Tentang Rumah Susun.

UU Republik Indonesia Nomor 4 Tahun 1992 Tentang Perumahan dan Pemukiman.

UU Republik Indonesia Nomor 28 Tahun 2002 Tentang Bangunan Gedung.

UU Republik Indonesia Nomor 1 Tahun 2011 Tentang Perumahan dan Kawasan Pemukiman.

Permen Pekerjaan Umum Nomor 06/Prt/M/2007 Tanggal 16 Maret 2007 Tentang Pedoman Umum Rencana Tata Bangunan dan Lingkungan. 
Jurnal Teknik Arsitektur ARTEKS, Volume. 2, Nomor 2, Juni 2018 ISSN 2541-0598 